TITLE:

\title{
Hepatic differentiation of embryonic stem cells by murine fetal liver mesenchymal cells.
}

$\operatorname{AUTHOR}(\mathrm{S})$ :

Ishii, Takamichi; Yasuchika, Kentaro; Ikai, Iwao

\section{CITATION:}

Ishii, Takamichi ... [et al]. Hepatic differentiation of embryonic stem cells by murine fetal liver mesenchymal cells.. Methods in molecular biology 2013, 946: 469-478

\section{ISSUE DATE:}

2013

URL:

http://hdl.handle.net/2433/168971

\section{RIGHT:}

The final publication is available at www.springerlink.com; This is not the published version. Please cite only the published version.; この論文 は出版社版でありません。引用の際には出版社版をご確認ご利用くだ さい。 


\section{Hepatic Differentiation of Embryonic Stem Cells by Murine Fetal Liver Mesenchymal Cells.}

Running title: Hepatic differentiation of ESCs by murine liver mesenchymal cell.

\section{Takamichi Ishii $^{1}$, Kentaro Yasuchika ${ }^{1}$, and Iwao Ikai ${ }^{1,2}$.}

1. Department of Surgery, Graduate School of Medicine Kyoto University.

2. Department of Surgery, Kyoto Medical Center, National Hospital Organization.

Contact information:

Takamichi Ishii, MD, Ph.D.

54 Kawahara-cho Shogoin Sakyo-ku, Kyoto, 606-8507, Japan

Tel: $+81-75-751-3242$

E-mail: taishii@kuhp.kyoto-u.ac.jp 


\section{i. Abstract}

Hepatocytes derived from embryonic stem cells (ESCs) are a potential cell source for regenerative medicine. However, it has been technically difficult to differentiate ESCs into mature hepatocytes because the definitive growth factors and molecular mechanisms governing hepatocyte differentiation have not yet been well defined. The $\mathrm{CD} 45^{-} \mathrm{CD} 49 \mathrm{f}^{+/-}$Thy $1^{+} \mathrm{gp} 38^{+}$mesenchymal cells that reside in murine fetal livers induce hepatic progenitor cells to differentiate into mature hepatocytes by direct cell-cell contact. Utilizing these cells, we employ a two-step procedure for hepatic maturation of ESC: first, ESCs are differentiated into endodermal cells or hepatic progenitor cells, and second, ESC-derived endodermal cells are matured into functional hepatocytes by co-culture with the murine fetal liver mesenchymal cells. The ESC-derived hepatocyte-like cells possess hepatic functions, including the ammonia removal activity, albumin secretion ability, glycogen synthesis and storage, and cytochrome P450 enzymatic activity.

ii. Keywords: embryonic stem cell; fetal liver; hepatocyte; hepatic progenitor cell; mesenchymal cell; Thy1; gp38. 


\section{Introduction}

Embryonic stem cells (ESCs) are established from inner cell masses and possess a

pluripotency to differentiate into all three germ layers. Hepatocytes derived from ESCs

are anticipated as a cell source for cell transplantation, bio-artificial livers, and drug

discovery support systems. However, there have been difficulties differentiating ESCs

into mature functional hepatocytes because the molecular mechanisms that underlie

hepatic development are largely unknown.

Our previous study revealed that the hepatic maturation of fetal hepatic progenitor cells

is greatly facilitated by mesenchymal cells that reside in the fetal livers (1). These

mesenchymal cells are fractionized as $\mathrm{CD} 45^{-} \mathrm{CD} 49 \mathrm{f}^{+-}$Thy $1^{+} \mathrm{gp} 38^{+}$cells $(2)$. In addition,

our further experiments demonstrated their ability to mature murine and human ESCs

into functional hepatocytes $(3,4)$. The effect of the CD $45^{-} \mathrm{CD}_{49 \mathrm{f}^{+-}} \mathrm{Thy}^{+} \mathrm{gp}^{\mathrm{g}} 8^{+}$

mesenchymal cells on hepatic maturation is achieved by direct cell-cell contact (5).

They do not induce hepatic maturation of undifferentiated ESCs, suggesting that

mesenchymal cells are effective in hepatic maturation of immature endodermal cells,

but are relatively ineffective at hepatic specification and differentiation of 
undifferentiated ESCs (4).

In this chapter, we describe a two-step procedure for the hepatic maturation of mouse ESCs utilizing the $\mathrm{CD} 45^{-} \mathrm{CD} 49 \mathrm{f}^{+/-}$Thy $1^{+} \mathrm{gp} 38^{+}$mesenchymal cells based on their biological characteristics. First, undifferentiated ESCs are differentiated into endodermal cells of the hepatic lineage using several growth factors and extracellular matrix. Second, the ESC-derived endodermal cells are matured into functional hepatocyte-like cells by co-culture with $\mathrm{CD} 45^{-} \mathrm{CD} 49 \mathrm{f}^{+/-}$Thy $1^{+} \mathrm{gp} 38^{+}$mesenchymal cells. 


\section{Materials}

\subsection{Culture of mouse ESCs}

1. A murine ESC line (see Note 1).

2. ESC culture medium: Dulbecco's modified Eagle's medium (DMEM) supplemented with $20 \%$ fetal bovine serum (FBS, HyClone, Logan, UT), $0.1 \mathrm{mM}$ 2-mercaptoethanol, nonessential amino acids, $1 \mathrm{mM}$ sodium pyruvate, and $1000 \mathrm{U} / \mathrm{ml}$ leukemia inhibitory factor (LIF, ESGRO, Chemicon International Inc., Temecula, CA) (see Note 2). A stock solution of $1 \times 10^{7} \mathrm{U} / \mathrm{ml} \mathrm{LIF}$ is stored at $4{ }^{\circ} \mathrm{C}$.

3. A solution of $0.25 \%$ trypsin and $1 \mathrm{mM}$ ethylenediaminetetraacetic acid (EDTA).

4. $35 \mathrm{~mm}$ plastic culture dishes with a mouse embryonic fibroblast (MEF) feeder layer treated with $10 \mu \mathrm{g} / \mathrm{ml}$ mitomycin C for 2 hours (see Note 3 ).

\subsection{Differentiation of ESCs into endoderm}

1. Serum-free endoderm differentiation medium (SFE medium): DMEM supplemented with 10\% Knockout SR (Gibco, Grand Island, NY), 2 mM L-glutamine, 1 mM sodium pyruvate, and penicillin/streptomycin (50 units/ml each). 
2. All-trans retinoic acid is dissolved at $10 \mathrm{mM}$ in $99.5 \%$ ethanol, and stored in aliquots at $-80{ }^{\circ} \mathrm{C}$. LIF is dissolved at $1 \times 10^{6} \mathrm{U} / \mathrm{ml}$ in a culture medium, and stored at $4{ }^{\circ} \mathrm{C}$.

Basic fibroblast growth factor (bFGF) and hepatocyte growth factor (HGF) are dissolved to a concentration of $20 \mu \mathrm{M}$ in phosphate-buffered saline (PBS, $\mathrm{Ca}^{2+}$-free) supplemented with $0.5 \%$ bovine serum albumin (BSA), and stored in aliquots at $-80{ }^{\circ} \mathrm{C}$. These growth factors are added to culture dishes as required (see Note 4).

3. $60 \mathrm{~mm}$ culture dishes coated with type I collagen (pre-coated dishes purchased from BD Biosciences, Franklin Lakes, NJ).

\subsection{Primary culture of murine fetal liver cells}

1. A stereomicroscope system.

2. A set of sterilized surgical instruments, including scissors, micro forceps, and a surgical knife.

3. A pair of sterilized surgical gloves.

4. Two pregnant C57/BL6 mice at day 13.5 of gestation (see Note 5).

5. HBSS-based buffer: $\mathrm{Ca}^{2+}$-free $\mathrm{Mg}^{+}$-free Hank's balanced salt solution with phenol red 
(HBSS (-)) with $10 \mathrm{mM}$ HEPES and $0.5 \mathrm{mM}$ EDTA.

6. Irrigation solution 1 (50 ml): HBSS-based buffer (45 ml) supplemented with $10 \%$

FBS $(5 \mathrm{ml})$, and $2 \mathrm{U} / \mathrm{ml}$ heparin sodium solution $(0.1 \mathrm{ml})$. Heparin sodium solution at $1000 \mathrm{U} / \mathrm{ml}$ is readily purchased from several pharmaceutical companies. This solution is prepared as required and kept at $4^{\circ} \mathrm{C}$ (see Note 6).

7. Irrigation solution $2(50 \mathrm{ml})$ : HBSS-based buffer (45 ml) supplemented with 50 $\mathrm{mg} / \mathrm{ml}$ DNase I (1 $\mathrm{ml}$ of stock solution), and $2 \mathrm{U} / \mathrm{ml}$ heparin sodium $(0.1 \mathrm{ml})$. DNase I is dissolved at $25 \mathrm{mg} / \mathrm{ml}$ in distilled water, and stored in single use aliquots at $-20^{\circ} \mathrm{C}$. This solution is prepared as required, and kept at $4{ }^{\circ} \mathrm{C}$ (see Note 7).

8. Digestion medium (30 ml): $0.5 \%(\mathrm{w} / \mathrm{v})$ collagenase type II (Gibco) is dissolved in 30 $\mathrm{ml}$ collagenase buffer and $0.1 \mathrm{ml}$ heparin sodium. This medium is kept at $37^{\circ} \mathrm{C}$ prior to use. Collagenase buffer contains $0.2 \mathrm{~g} \mathrm{MgSO}_{4} \cdot 7 \mathrm{H}_{2} \mathrm{O}, 0.735 \mathrm{~g} \mathrm{CaCl}_{2} \cdot 2 \mathrm{H}_{2} \mathrm{O}, 2.383 \mathrm{~g}$ HEPES, and $0.05 \mathrm{~g}$ trypsin inhibitor in $11 \mathrm{HBSS}(-)$. This buffer can be preserved at 4 ${ }^{\circ} \mathrm{C}$ for a month.

9. Hepatocyte differentiation medium (HD medium): DMEM with 10\% FBS, $1 \mathrm{mM}$ sodium pyruvate, penicillin/streptomycin (50 units/ml each), $10 \mathrm{mM}$ nicotinamide, 2 
mM L-ascorbic acid phosphate, insulin-transferrin-selenium supplement mixture

(Gibco), $1 \times 10^{-7} \mathrm{M}$ dexamethasone, $20 \mathrm{ng} / \mathrm{ml} \mathrm{HGF}$, and $10 \mathrm{ng} / \mathrm{ml}$ oncostatin $\mathrm{M}$.

Oncostatin $\mathrm{M}$ is dissolved at $10 \mathrm{mg} / \mathrm{ml}$ in $0.5 \% \mathrm{BSA} / \mathrm{PBS}$, and stored at $-80{ }^{\circ} \mathrm{C}$. This medium can be preserved at $4{ }^{\circ} \mathrm{C}$ for a month, and should be kept at $37^{\circ} \mathrm{C}$ before use.

10. Autoclaved nylon meshes with $50 \mu \mathrm{m}$ and $100 \mu \mathrm{m}$ pore size.

11. $100 \mathrm{~mm}$ and $35 \mathrm{~mm}$ Petri dishes (BD Biosciences).

12. 6-well culture plates coated with type I collagen (pre-coated culture plates

purchased from BD Biosciences).

13. A water bath at $37^{\circ} \mathrm{C}$.

\subsection{Isolation of murine fetal liver mesenchymal cells using flow cytometry}

1. Solution of $0.25 \%$ trypsin-EDTA.

2. PBS (30 ml) with $3 \%$ FBS (1ml) (3\%FBS/PBS).

3. The following antibodies are used:

Anti-CD45-PE (clone 30-F11, diluted at 1:100, BD Biosciences)

Anti-CD49f-PE (clone GoH3, 3:100, BD Biosciences) 
Anti-Thy1-FITC (clone 30-H12, 1:100, BD Biosciences)

Anti-gp38 (Podoplanin, 1:100, Medical and Biological Laboratories, Nagoya, Japan)

The anti-gp38 antibody is conjugated with APC using a conjugation kit (see Note 8).

4. $5 \mathrm{ml}$ round-bottom tubes with $35 \mu \mathrm{m}$ nylon meshes.

5. FACSVantage SE (BD Biosciences).

6. HD medium (see subheading 2.3.9).

7. 24-well culture plates coated with type I collagen (pre-coated plates from BD

Biosciences).

2.5. Co-culture of ESC-derived endodermal cells and murine fetal liver mesenchymal

cells

1. A 24-well culture plate coated with type I collagen with murine fetal liver

mesenchymal cells as a feeder layer.

2. HD medium (see subheading 2.3.9). 


\section{Methods}

\subsection{Culture of ESC}

Mouse ESCs are cultured in the undifferentiated state on MEF feeder layers (6, 7). They are sub-cultured using $0.25 \%$ trypsin/EDTA solution. MEFs are prepared according to the standard protocols.

\subsection{Differentiation of ESCs into endodermal cells}

1. Undifferentiated mouse ESCs that are maintained on $60 \mathrm{~mm}$ culture dishes are washed $4 \mathrm{ml}$ PBS twice, added $2 \mathrm{ml} 0.25 \%$ trypsin/EDTA solution at $37^{\circ} \mathrm{C}$ for $2 \mathrm{~min}$, and then added $2 \mathrm{ml}$ ESC medium followed by pipetting well to dissociate. They are centrifuged at $180 \mathrm{~g}$ for $3 \mathrm{~min}$, and resuspended with $4 \mathrm{ml}$ ESC medium. In order to deplete MEFs, the dissociated cells are transferred onto a plastic culture dish in ESC culture medium, and incubated at $37^{\circ} \mathrm{C}$ for 15 to $30 \mathrm{~min}$.

2. The cell suspension is harvested carefully to avoid removal of the adherent cells and centrifuged at $180 \mathrm{~g}$ for $3 \mathrm{~min}$. The cell pellet is suspended and plated at a concentration of $1 \times 10^{5}$ cells $/ \mathrm{ml}$ on $60 \mathrm{~mm}$ culture dishes coated with type I collagen in SFE medium 
(see Note 9).

3. $10 \mu \mathrm{M}$ ATRA and $1000 \mathrm{U} / \mathrm{ml} \mathrm{LIF}$ are added to the SFE medium for the first two days

(days $0-1$ ), and $20 \mathrm{ng} / \mathrm{ml} \mathrm{HGF}$ and $20 \mathrm{ng} / \mathrm{ml} \mathrm{bFGF}$ are added for the next five days

(days 2-6). Culture medium should be changed every other day at least.

4. At day 7 , the cultured cells are dissociated using a $0.25 \%$ trypsin/EDTA solution ( $d o$ as subheading 3.2.1) and re-suspend with HD medium for further experiments (see subheading 3.5) (see Note 10).

\subsection{Primary culture of murine fetal liver cells}

1. Two timed-pregnant mice are sacrificed according to institutional guidelines. All uteri are removed and placed into a $100 \mathrm{~mm}$ Petri dish with cold irrigation solution 1.

Amniotic membranes and placentae are removed, and fetal mice are transferred to a new $100 \mathrm{~mm}$ Petri dish with cold irrigation solution 1.

2. The liver tissues are dissected under a stereomicroscope (Fig. 1), and placed into a new $100 \mathrm{~mm}$ Petri dish with cold irrigation solution 1 . The harvested livers are then minced into pieces no larger than $1 \mathrm{~mm}$ in diameter with a surgical knife. 
3. A nylon mesh $(50 \mu \mathrm{m}$ pore size $)$ is placed on a $50 \mathrm{ml}$ centrifuge tube. The minced liver tissues are filtered through this mesh. The mesh is inverted and carefully transferred onto a new $50 \mathrm{ml}$ centrifuge tube (see Note 11). The flow-through can be discarded.

4. Warm digestion medium $(30 \mathrm{ml})$ is added through the inverted mesh into the $50 \mathrm{ml}$ centrifuge tube, collecting the liver tissues into the tube together with the digestion medium. The tube is incubated in a water bath at $37^{\circ} \mathrm{C}$ for 12 to 15 min with agitation. 5. Four nylon meshes $(100 \mu \mathrm{m}$ pore size $)$ are placed onto four $15 \mathrm{ml}$ centrifuge tubes. The digested tissues are divided into four equal aliquots, filtered through meshes using a pipette, collected in the centrifuge tubes, and then centrifuged at $10 \mathrm{~g}$ for $5 \mathrm{~min}$ (see

\section{Note 12).}

6. The cell pellet is suspended in $25 \mathrm{ml}$ irrigation solution 2 , collected in a $15 \mathrm{ml}$ centrifuge tube, and then centrifuged at $10 \mathrm{~g}$ for $5 \mathrm{~min}$. This procedure is repeated three times in total.

7. The cell pellet is suspended in HD medium at a density of $5 \times 10^{5}$ cells $/ \mathrm{ml}$ to $1 \times 10^{6}$ cells/ml, and inoculated onto $35 \mathrm{~mm}$ Petri dishes (see Note 13). 
8. The dissociated cells are incubated at $37{ }^{\circ} \mathrm{C}, 5 \% \mathrm{CO}_{2}$ overnight. Cell aggregates are collected in a $15 \mathrm{ml}$ tube and subjected to gravity sedimentation for $10 \mathrm{~min}$ (see Note 14).

9. After the supernatant is removed with a pipette, the sedimented cell aggregates are suspended in new HD media and plated on 6-well culture plates coated with type I collagen (see Note 15).

10. The cell aggregates are cultured at $37^{\circ} \mathrm{C}, 5 \% \mathrm{CO}_{2}$ for one to two days. The culture media are changed every day. The cell aggregates adhere to the culture plates and grow as monolayer colonies.

\subsection{Preparation of $\mathrm{CD}^{-} 5^{-} \mathrm{CD} 49 \mathrm{f}^{+/-} \mathrm{Thy}^{+} \mathrm{gp}^{+} 8^{+}$mesenchymal cells as a feeder layer}

A key step in this procedure is to obtain a pure and viable cell fraction of the mesenchymal cells from murine fetal livers.

1. Following 1-2 days of culture, the adherent cells are washed twice with $500 \mu$ PBS and are then incubated with $200 \mu 10.25 \%$ trypsin/EDTA at $37^{\circ} \mathrm{C}$ for $10 \mathrm{~min}$. HD medium is added to stop trypsin activity, and all of the cell suspension is collected in a 
$15 \mathrm{ml}$ tube.

2. The collected cells are centrifuged at $180 \mathrm{~g}$ for $3 \mathrm{~min}$, and then washed with $5 \mathrm{ml} 3 \%$

FBS/PBS twice by centrifuging at $180 \mathrm{~g}$ for $3 \mathrm{~min}$.

3. The cell pellet is suspended in $200 \mu 13 \%$ FBS/PBS, and transferred into a $1.5 \mathrm{ml}$ tube.

The dissociated cells are incubated with $2 \mu$ l CD45-PE (1:100 dilution), $6 \mu$ l CD49f-PE

(3:100), $2 \mu 1$ Thy1-FITC (1:100), and $2 \mu 1$ gp38-APC (1:100) antibodies on ice in the dark for $30 \mathrm{~min}$.

4. The cells are centrifuged at $630 \mathrm{~g}$ for $2 \mathrm{~min}$, and then the supernatant is discarded.

5. The cells are washed with $500 \mu 13 \%$ FBS/PBS three times.

6. The cells are resuspended in 2 to $4 \mathrm{ml} \mathrm{3 \%} \mathrm{FBS/PBS} \mathrm{and} \mathrm{collected} \mathrm{in} \mathrm{a} 5 \mathrm{ml}$

round-bottom tube through a nylon mesh $(35 \mu \mathrm{m}$ pore size $)$.

7. The CD $45^{-} \mathrm{CD} 49 \mathrm{f}^{+/-}$Thy $1^{+} \mathrm{gp} 38^{+}$cell fraction is separated using a FACSVantage SE.

Dot plots using CD45, CD49f, Thy1, and gp38 antibodies are shown in Fig. 2 (see Note

16). The separated $\mathrm{CD} 45^{-} \mathrm{CD} 49 \mathrm{f}^{+--}$Thy $1^{+} \mathrm{gp} 38^{+}$mesenchymal cells are collected in HD medium.

8. The collected cells are suspended in HD medium and seeded in 24-well culture plates 
coated with collagen type I at a density of $1 \times 10^{4}$ cells per well (see Note 17).

9. The $\mathrm{CD} 45^{-} \mathrm{CD} 49 \mathrm{f}^{+/-}$Thy $1^{+} \mathrm{gp} 38^{+}$mesenchymal cells are grown to approximately $80 \%$ confluency and treated with $10 \mu \mathrm{g} / \mathrm{ml}$ mitomycin $\mathrm{C}$ for 2 hours. After washing twice in PBS, fresh HD medium is added. The inactivated cells can be used from the next day.

\subsection{Maturation of ESC-derived endodermal cells}

1. The dissociated endoderm cells derived from mouse ESCs, generated in section 3.2, are inoculated on a feeder layer of $\mathrm{CD} 45^{-} \mathrm{CD} 49 \mathrm{f}^{+/-}$Thy $1^{+} \mathrm{gp} 38^{+}$mesenchymal cells at a density of $1 \times 10^{4}$ cells/well (see Note $\mathbf{1 8}$ ).

2. The ESC-derived endoderm cells are cultured in HD medium on the

$\mathrm{CD} 45^{-} \mathrm{CD} 49 \mathrm{f}^{+/-} \mathrm{Thy}^{+}{ }^{+} \mathrm{gp} 38^{+}$mesenchymal feeder layer for 7 to 14 days. Culture media are changed every day.

3. These ESC-derived mature hepatocyte-like cells can be used for further analyses including drug metabolism and albumin secretion. 


\section{Notes}

1. In this protocol, a murine ESC line derived from C57BL6 mice are used. The passage

number is less than 50. Our protocol works with a human ESC line (4).

2. Because ESC culture medium contains LIF, it should be used within a month.

3. Culture dishes with a MEF-feeder layer can be used for one week after mitomycin C treatment.

4. Unless stated otherwise, growth factors are added from stock solutions to culture medium as required.

5. The number of pregnant mice can be increased to four mice per experiment. In this case, the described protocol can be scaled up. However, it might be technically difficult to handle more than five mice at one time since it may be more time-consuming, decreasing the viability of harvested liver cells.

6. Heparin is added in order to prevent clot formation.

7. DNase is added in order to reduce viscosity caused by DNA that is released from damaged cells.

8. The combination of the fluorescent dyes is actually atypical, because PE labels both 
anti-CD45 and anti-CD49f antibodies. However, as shown in Fig. 2, the CD45-positive cell fraction is clearly distinguishable from the CD49f-positive cell fractions based on their fluorescent intensities (1). This may result from the difference in the expression levels between CD45 and CD49f antigens.

9. Usually two to four $60 \mathrm{~mm}$ collagen type I coated dishes can be harvested from undifferentiated ESCs on one confluent $60 \mathrm{~mm}$ dish. The concentration of ESCs seeded on culture plates is important. Under this condition, differentiating ESCs can be cultured for seven days without further passages. During this period, culture medium should be changed every other day. 10. This protocol makes it possible to obtain alpha-fetoprotein (AFP)-producing endodermal cells at the efficiency of more than $40 \%$ at day 7 . However, the optimal condition for endodermal differentiation may vary widely with the type of ESCs. For example, our recent study revealed that ATRA does not induce hepatic differentiation in human ESCs, and that Matrigel (BD Biosciences) is more efficient for hepatic differentiation than Type I Collagen (8). Therefore, culture protocols may require optimization depending on the ESC lines. 
11. Because fetal livers act as hematopoietic organs during embryonic stages, the harvested liver tissues contain a large number of hematopoietic cells. This procedure is necessary in order to eliminate hematopoietic cells. The flow-through contains hematopoietic cells.

12. This procedure is performed to eliminate undigested liver tissues.

13. The harvested liver cells obtained from one pregnant mouse can usually be seeded onto three $35 \mathrm{~mm}$ Petri dishes, although the yield depends on the number of fetuses. 14. The cell aggregates can be formed in a few hours. The cell aggregates consist of hepatic progenitor cells, hematopoietic cells, and mesenchymal cells. Forming cell aggregates can enrich hepatic progenitor cells and mesenchymal cells, and greatly facilitate the purification of mesenchymal cells using flow cytometry (9).

15. The cell aggregates cultured in one $35 \mathrm{~mm}$ Petri dish can be usually transferred to one well of a 6-well culture plate.

16. This protocol can be also used to separate hepatic progenitor cells that reside in fetal murine livers. The $\mathrm{CD} 45^{-} \mathrm{CD} 49 \mathrm{f}^{+/-}$Thy $1^{-}$cell fraction corresponds to hepatic progenitor cells. In this case, it is best to set a small gate for the $\mathrm{CD} 45^{-} \mathrm{CD} 49 \mathrm{f}^{+/-}$Thy $1^{-}$fraction in 
order to obtain a pure fraction of hepatic progenitor cells.

17. Cell viability is remarkably decreased at a lower density of cultured cells.

Eventually, $1.5-2.0 \times 10^{4} \mathrm{CD} 45^{-} \mathrm{CD} 49 \mathrm{f}^{+-}$Thy $1^{+} \mathrm{gp} 38^{+}$mesenchymal cells can be isolated from one pregnant mouse.

18. The ESC-derived endodermal cells consist of not only endodermal cells, but also ectodermal and mesodermal cells. Therefore, experimental circumstances may require purification of only endodermal cells. In these cases, it may be helpful to generate transgenic ESCs that express fluorescent proteins driven by an endoderm-specific gene (e.g. AFP or albumin) promoter by gene manipulation $(3,10)$. 


\section{Acknowledgements}

The authors would like to thank Prof. Norio Nakatsuji (Institute for Integrated

Cell-Material Science, Kyoto University), Dr. Hirofumi Suemori (Institute for Frontier

Medical Sciences, Kyoto University), and Prof. Shinji Uemoto (Graduate School of

Medicine Kyoto University) for supporting the study. This work was supported in part

by grants from the Scientific Research Fund of Ministry of Education, Culture, Sports,

Science, and Technology of Japan. 


\section{Figure legends}

Fig. 1

This photograph shows a mouse fetus after removal of the amniotic membrane and

placenta. The fetal liver is a red organ located in the middle of a fetus. Under a stereomicroscope, the liver is dissected using micro forceps. The gallbladder and intestinal tract should be removed from the liver.

Fig. 2

Dot plots following flow cytometric analyses. (A) Cell aggregates derived from murine fetal livers are mainly divided by CD45, CD49f, and Thy1 into three cell fractions. The $\mathrm{CD} 45^{+}$Thy $1^{-}$fraction corresponds to hematopoietic cells, the $\mathrm{CD} 45^{-} \mathrm{CD} 49 \mathrm{f}+{ }^{\mathrm{dim}} \mathrm{Thy} 1^{-}$ cell fraction corresponds to hepatic progenitor cells, and the $\mathrm{CD} 45^{-} \mathrm{CD} 49 \mathrm{f}^{+/-}$Thy $1^{+}$cell fraction is mesenchymal cells. (B) The $\mathrm{CD} 45^{-} \mathrm{CD} 49 \mathrm{f}^{+/-}$Thy $1^{+}$mesenchymal cells are further fractionated by gp38 into two groups. The gp38-positive cells account for approximately $16 \%$ of the $\mathrm{CD} 45^{-} \mathrm{CD} 49 \mathrm{f}^{+/-}$Thy $1^{+}$mesenchymal cells. 


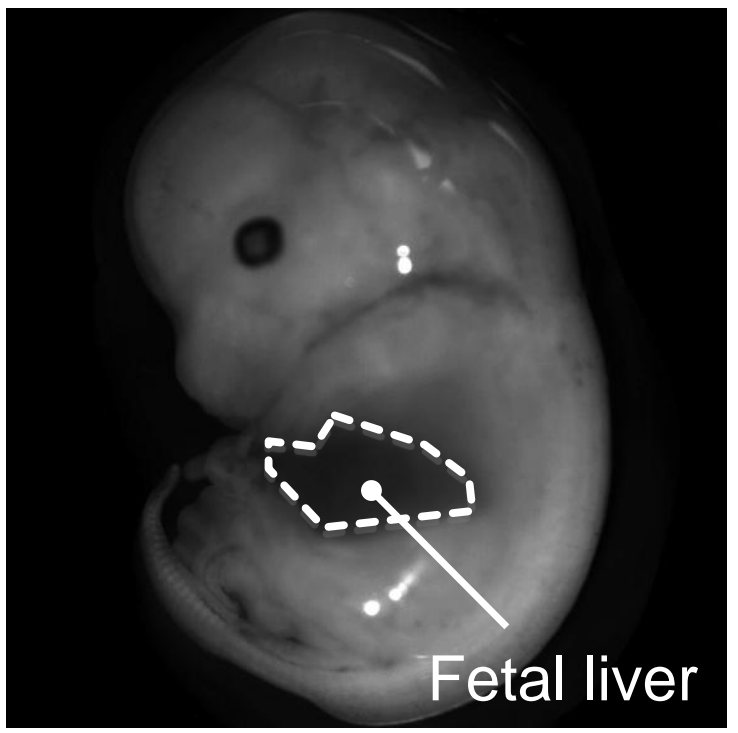


A. Cell aggregates from fetal livers

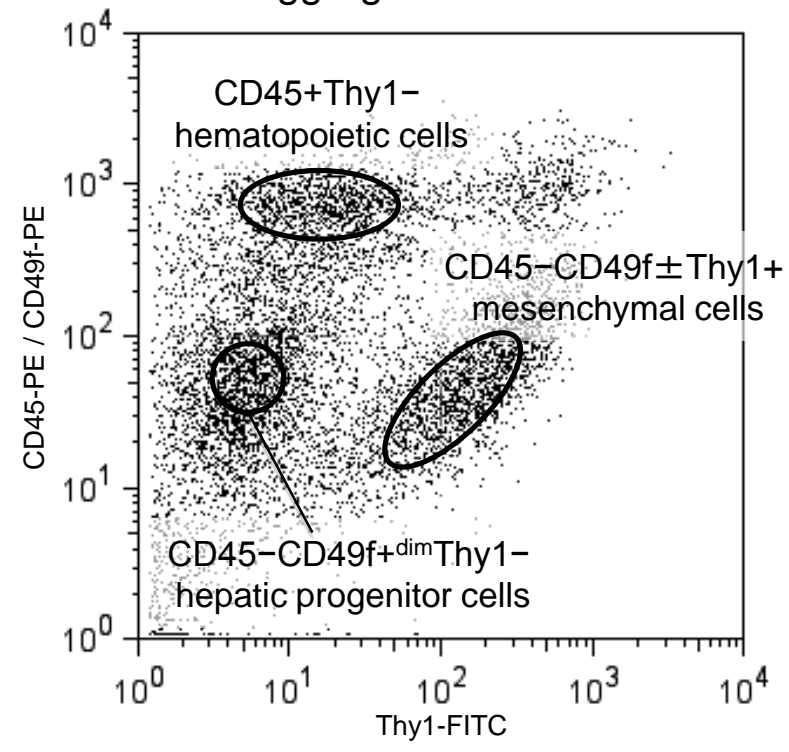

B. CD45-CD49f \pm Thy1- mesenchymal cells

$$
10^{4}
$$$$
\text { CD45-CD49f } \pm \text { Thy1+gp38+ }
$$

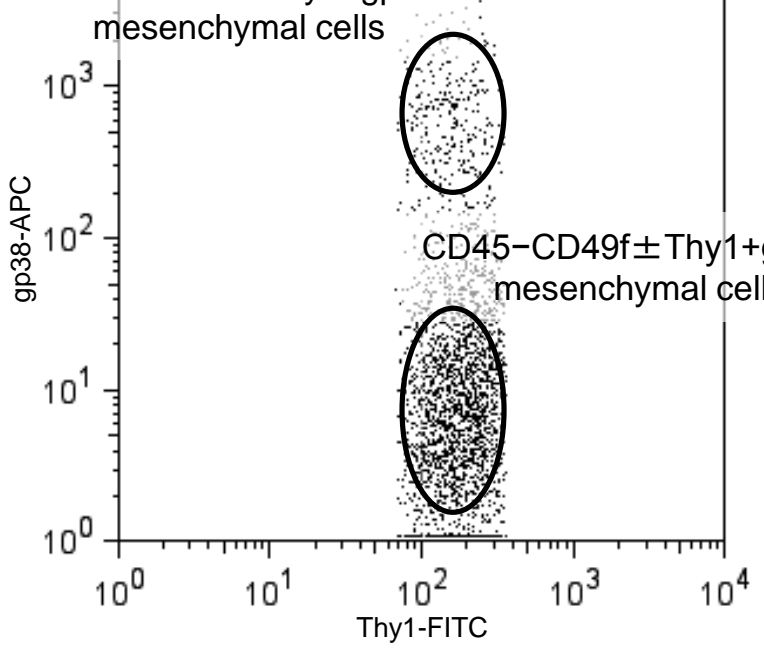




\section{References}

1. Hoppo T, Fujii H, Hirose T, Yasuchika K, Azuma H, Baba S, Naito M, Machimoto T,

Ikai I (2004) Thy1-positive mesenchymal cells promote the maturation of

CD49f-positive hepatic progenitor cells in the mouse fetal liver. Hepatology

$39: 1362-1370$

2. Kamo N, Yasuchika K, Fujii H, Hoppo T, Machimoto T, Ishii T, Fujita N, Tsuruo T,

Yamashita JK, Kubo H, Ikai I (2007) Two populations of Thy1-positive mesenchymal

cells regulate in vitro maturation of hepatic progenitor cells. Am J Physiol Gastrointest

Liver Physio 292:G526-534

3. Ishii T, Yasuchika K, Fujii H, Hoppo T, Baba S, Naito M, Machimoto T, Kamo N,

Suemori H, Nakatsuji N, Ikai I (2005) In vitro differentiation and maturation of mouse

embryonic stem cells into hepatocytes. Exp Cell Res 309:68-77

4. Ishii T, Yasuchika K, Fukumitsu K, Kawamoto T, Kawamura-Saitoh M, Amagai Y,

Ikai I, Uemoto S, Kawase E, Suemori H, Nakatsuji N (2010) In vitro hepatic maturation

of human embryonic stem cells by using a mesenchymal cell line derived from murine

fetal livers. Cell Tissue Res 339:505-512 
5. Fukumitsu K, Ishii T, Yasuchika K, Amagai Y, Kawamura-Saito M, Kawamoto T,

Kawase E, Suemori H, Nakatsuji N, Ikai I, Uemoto S (2009) Establishment of a cell

line derived from a mouse fetal liver that has the characteristic to promote the hepatic

maturation of mouse embryonic stem cells by a coculture method. Tissue Eng Part A

$15: 3847-3856$

6. Sumi T, Tsuneyoshi N, Nakatsuji N, Suemori H (2007) Apoptosis and differentiation

of human embryonic stem cells induced by sustained activation of c-Myc. Oncogene

26:5564-5576.

7. Suemori H, Yasuchika K, Hasegawa K, Fujioka T, Tsuneyoshi N, Nakatsuji N (2006)

Efficient establishment of human embryonic stem cell lines and long-term maintenance

with stable karyotype by enzymatic bulk passage. Biochem Biophys Res Commun

345:926-932.

8. Ishii T, Fukumitsu K, Yasuchika K, Adachi K, Kawase E, Suemori H, Nakatsuji N,

Ikai I, Uemoto S (2008) Effects of extracellular matrixes and growth factors on the

hepatic differentiation of human embryonic stem cells. Am J Physiol Gastrointest Liver

Physiol 295:G313-321 
9. Yasuchika K, Hirose T, Fujii H, Oe S, Hasegawa K, Fujikawa T, Azuma H,

Yamaoka Y (2002) Establishment of a highly efficient gene transfer system for mouse fetal hepatic progenitor cells. Hepatology 36:1488-1497

10. Ishii T, Yasuchika K, Machimoto T, Kamo N, Komori J, Konishi S, Suemori H, Nakatsuji N, Saito M, Kohno K, Uemoto S, Ikai I (2007) Transplantation of embryonic stem cell-derived endodermal cells into mice with induced lethal liver damage. Stem Cells 25:3252-3260 